\title{
Determination of Navel Orange Safety Production Traceability Information Based on HACCP
}

\author{
Haiyan $\mathrm{Hu}^{1,2}$, Huoguo Zheng ${ }^{1,2}$, and Shihong $\mathrm{Liu}^{1,2}$ \\ ${ }^{1}$ Key Laboratory of Digital Agricultural Early-warning Technology of Ministry of Agriculture, \\ The People's Republic of China, Beijing 100081, Beijing, China \\ ${ }^{2}$ Agricultural Information Institute of Chinese Academy of Agriculture Science, \\ Beijing 100081, Beijing, China \\ \{huhaiyan, lius\}@mail.caas.net.cn, huoguo@caas.net.cn
}

\begin{abstract}
The traceability system of navel orange can ensure the quality and safety due to the whole process control from orchard to market. Research on the whole process of navel orange is the foundation and premise of building the traceability system. Based on the analyses of whole food chain of navel orange from origin to market, HACCP is used to evaluate the risk and latent risk of the food chain of navel orange: planting, harvesting, processing, packing, transportation and sale, the critical control point of navel orange were fixed. Further, the traceability information of the navel orange traceability is determinate finally.
\end{abstract}

Keywords: navel orange, critical control point, traceability information, HACCP.

\section{Introduction}

After several food safety related issues, particularly several food sandals, the global food industry and governments in many countries have paid more and more attention to traceability systems for the food chain [1]. There are three meaning to construct traceability systems: one is to give consumers the right to know, the second is to strengthen the responsibility for the enterprises which produce food, and the third is to find the root causes when the food safety issues happened [2].

Navel orange is one of characteristic agricultural products in the middle of china, which is demanding climate for growing. The origin of the navel orange mainly existed in south Jiangxi province, zigui, Hubei province, fengjie, Chongqing province, binzhou, Yunnan province. Gannan is the advantageous product area for navel orange determined by ministry of Agriculture in China. Gannan is the famous base for navel orange, where is known as "town of navel orange in China". Many counties in Gannan have taken navel orange as an important tool for local farmer income. The navel orange produced in Gannan has many unique features, such as large shaped, bright color, crisp flesh and good taste.

However, the incidents occurred in recently years, such as "dyeing navel orange" in Hong Kong in 2004, "bactrocera minax" in guangyuan city, Sichuan province in 
2008, have damaged the orange industry in south of china. For example ,the "dyeing navel orange" incident made $70 \%$ order in Hong Kong cancellation, the price of navel orange fell sharply in 2004. In 2008, affected by the "bactrocera minax" incident, all of the consumers don't want to buy navel orange in china. These events cause severe economic losses to fruit growers.

In order to guarantee the quality safety of navel orange, make sure the quality safety information can be tracked and traced, we should monitor the whole process from tree planting to sale [3], which also called "management from orchard to table". As for navel orange, confirm the critical control point based on the analysis of the whole process from tree planting to fruit processing with the HACCP (Hazard Analysis and Critical Control Point)[4] is the foundation of traceability system construction.

\section{Navel Orange Production Process Analysis}

\subsection{Navel Orange Production Process from Orchard to Market}

Generally, there are 11 steps from navel orange tree planting to navel orange fruit sale on market: orchard selection, sapling selection, planting, tree management, soil fertilizer and water management, flower and fruit management, insect control, harvest, washing and packing, storage and transportation [5]. The whole process is shown as Fig. 1.

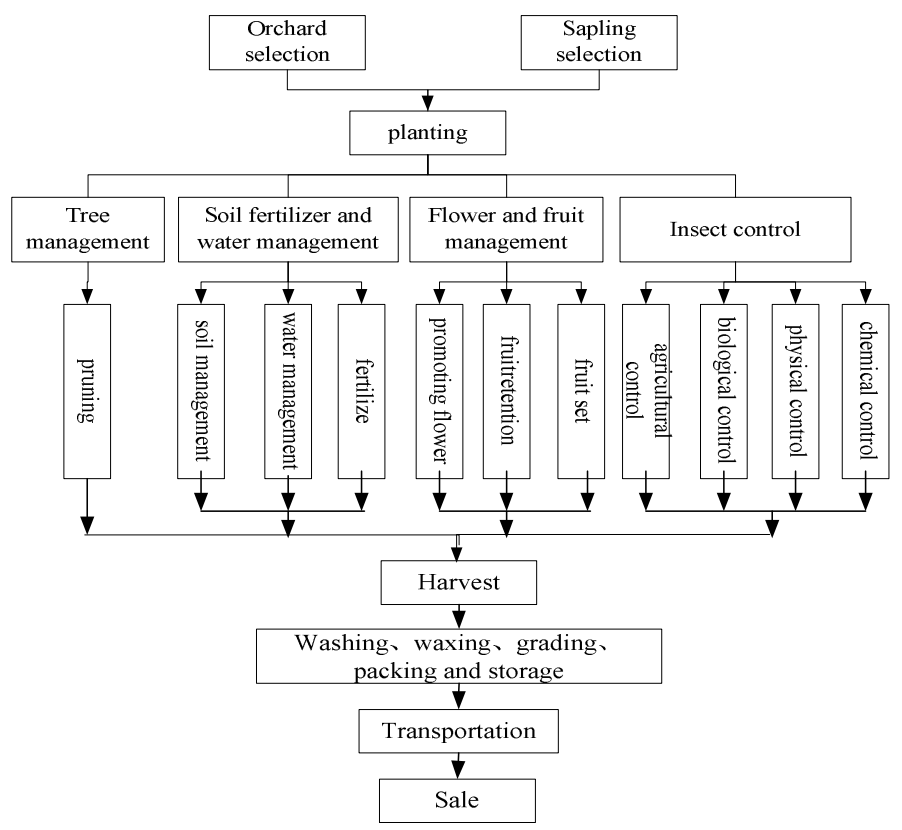

Fig. 1. 11 steps of navel orange growing 
It needs 2-3 years from tree planting to bear fruit for navel orange tree, and it needs 280-300 days from blooming to outcome for navel orange. There are a lot of links and elements affect the quality safety for navel orange.

\subsection{Navel Orange Main Hazard Analysis}

Generally, there are three kinds of hazard to person in fresh agricultural products: biological hazards, chemical hazards and physical hazards.

The biological hazards of navel orange mainly refer to the biological itself and its metabolites will pollute fruit raw materials, process and products. This pollution will damage consumer's safety. As for fruit, hazard generated creatures are fungi, bacteria, viruses, natural toxins, parasites. Specifically, ulcers are the most occurred bacterial diseases for navel orange, which damage a lot to navel orange.

The chemical hazards of navel orange mainly refer to chemical substances, residues and emissions generated by human activities, which contaminated the fruit. Chemical hazards involves a broader range, including environmental pollution, pesticide residues fertilizer residues, chemical element pollution, packaging materials, such pollution damages the health of consumers. For navel orange, atmospheric pollutants are same with other fruits, including total suspended particulates, sulfur dioxide, nitrogen dioxide, and fluoride. Soil contaminants in navel orange include heavy metals, toxic substances (pesticides, various chemicals) and other pollutants. Soil pollution comes mainly from three aspects: First, the discharge of industrial waste; second pesticide, fertilizer application, etc.; third of sewage irrigation.

Physical hazards of navel orange exist in fruit with potentially harm may cause bodily injury to consumers., which are common glass, wire, nails fragments, stones fragments, metal fragments and so on.

\section{Analysis of Navel Orange Critical Control Point for Safety Production}

\subsection{Navel Orange Safety Element Analysis}

As we known, navel orange can be sold on market after 11 steps. Among all of these process, potential hazard factors include: environmental conditions, water quality, pesticide residues, etc, which we should analyses detailed from biological hazards, chemical hazards and physical hazards three aspects, then identify the significant hazards [6].

Chemical hazards that can impact navel orange safety mainly in the following five areas: first, pesticide residues as well as mercury, cadmium, lead, tin, chromium, arsenic, fluoride and other harmful substances residues in soil; second, fluoride and sulfide in air; third, pesticide residues and mercury, cadmium, lead, tin, chromium, arsenic, fluoride residues in irrigation water, fourth, mercury, cadmium, lead, tin, chromium, arsenic, fluorine, and antibiotics residues in fertilizer; fifth, pesticides and heavy metals exceeded in the fruit during the pest control process.

There is no physical hazard to customers in navel orange basically. 


\subsection{Critical Control Points of Navel Orange}

Based on the whole process of navel orange and information of hazard analysis, five critical control points was determined (shown in Table 1):

(1) Surroundings, soil properties, pesticide residues and harmful substances in the orchard.

(2) Pesticides in the pest control.

(3) Disinfectant and wax during the washing, waxing.

(4) Pathogens during transportation

(5) Pathogens in market.

Table 1. HACCP based Hazard analysis of navel orange

\begin{tabular}{|c|c|c|c|c|c|}
\hline $\begin{array}{c}\text { Production } \\
\text { process }\end{array}$ & Hazard type & \begin{tabular}{|c|} 
Is \\
significant?
\end{tabular} & $\begin{array}{l}\text { Judgments based on the } \\
\text { third column }\end{array}$ & Precaution & $\begin{array}{c}\text { Is } \\
\text { CCP? }\end{array}$ \\
\hline \multirow{3}{*}{$\begin{array}{l}\text { Orchard } \\
\text { selection }\end{array}$} & $\begin{array}{l}\text { biological } \\
\text { hazard }\end{array}$ & No & & & No \\
\hline & $\begin{array}{l}\text { chemical } \\
\text { hazard }\end{array}$ & Yes & 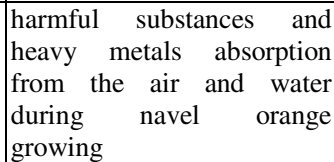 & $\begin{array}{l}\text { test the soil, air and } \\
\text { water, make sure all of } \\
\text { them line with national } \\
\text { standards }\end{array}$ & Yes \\
\hline & \begin{tabular}{|l|} 
physical hazard \\
\end{tabular} & No & & & No \\
\hline \multirow{3}{*}{$\begin{array}{l}\text { Sapling } \\
\text { selection }\end{array}$} & $\begin{array}{l}\text { biological } \\
\text { hazard }\end{array}$ & No & & & No \\
\hline & $\begin{array}{l}\text { chemical } \\
\text { hazard }\end{array}$ & No & & & No \\
\hline & physical hazard & No & & & No \\
\hline \multirow{3}{*}{ Planting } & $\begin{array}{l}\text { biological } \\
\text { hazard }\end{array}$ & No & & & No \\
\hline & \begin{tabular}{|l|} 
chemical \\
hazard
\end{tabular} & No & & & No \\
\hline & physical hazard & No & & & No \\
\hline \multirow{3}{*}{$\begin{array}{l}\text { Navel } \\
\text { orange tree } \\
\text { management }\end{array}$} & $\begin{array}{l}\text { biological } \\
\text { hazard }\end{array}$ & No & & & No \\
\hline & $\begin{array}{l}\text { chemical } \\
\text { hazard }\end{array}$ & Yes & Use growth regulator & limited & No \\
\hline & physical hazard & No & & & No \\
\hline \multirow{3}{*}{$\begin{array}{l}\text { Soil } \\
\text { management }\end{array}$} & \begin{tabular}{|l} 
biological \\
hazard
\end{tabular} & No & & & No \\
\hline & \begin{tabular}{|l|} 
chemical \\
hazard
\end{tabular} & Yes & Use steamed soil fumigant & limited & No \\
\hline & physical hazard & No & & & No \\
\hline \multirow{3}{*}{$\begin{array}{l}\text { Irrigation } \\
\text { management }\end{array}$} & $\begin{array}{l}\text { biological } \\
\text { hazard }\end{array}$ & No & & & No \\
\hline & $\begin{array}{l}\text { chemical } \\
\text { hazard }\end{array}$ & Yes & $\begin{array}{l}\begin{array}{l}\text { Irrigation water contain } \\
\text { harmful substances, heavy } \\
\text { metals }\end{array} \\
\end{array}$ & $\begin{array}{l}\text { make sure water line } \\
\text { with national standards }\end{array}$ & No \\
\hline & physical hazard & No & & & No \\
\hline \multirow{3}{*}{$\begin{array}{l}\text { Fertilize } \\
\text { management }\end{array}$} & \begin{tabular}{|l} 
biological \\
hazard
\end{tabular} & No & fertilizer storage & $\begin{array}{l}\text { separate the fertilizer } \\
\text { and fruit }\end{array}$ & No \\
\hline & $\begin{array}{l}\text { chemical } \\
\text { hazard }\end{array}$ & Yes & $\begin{array}{l}\text { Fertilizer contain harmful } \\
\text { substances, chemical and } \\
\text { heavy metals }\end{array}$ & $\begin{array}{l}\text { Handle the organic } \\
\text { fertilizer before use }\end{array}$ & No \\
\hline & physical hazard & No & & & No \\
\hline
\end{tabular}


Table 2. (Continued)

\begin{tabular}{|c|c|c|c|c|c|}
\hline \multirow{3}{*}{$\begin{array}{l}\text { Flower } \\
\text { management }\end{array}$} & $\begin{array}{l}\text { biological } \\
\text { hazard }\end{array}$ & No & & & No \\
\hline & $\begin{array}{l}\text { chemical } \\
\text { hazard }\end{array}$ & Yes & Use fruit growth regulator & limited & No \\
\hline & physical hazard & No & & & No \\
\hline \multirow{3}{*}{ Pest control } & $\begin{array}{l}\text { biological } \\
\text { hazard }\end{array}$ & Yes & Use biological pesticide & $\begin{array}{|ll|}\text { line with national } \\
\text { standards }\end{array}$ & No \\
\hline & $\begin{array}{l}\text { chemical } \\
\text { hazard }\end{array}$ & Yes & Use chemical pesticide & $\begin{array}{ll}\text { line with national } \\
\text { standards }\end{array}$ & Yes \\
\hline & physical hazard & No & & & No \\
\hline \multirow{3}{*}{ Harvest } & $\begin{array}{l}\text { biological } \\
\text { hazard }\end{array}$ & No & & & No \\
\hline & \begin{tabular}{|l} 
chemical \\
hazard
\end{tabular} & Yes & & & No \\
\hline & physical hazard & No & & & No \\
\hline \multirow{3}{*}{$\begin{array}{l}\text { Washing、 } \\
\text { waxing、 } \\
\text { grading、 } \\
\text { packing }\end{array}$} & \begin{tabular}{|l|} 
biological \\
hazard
\end{tabular} & No & & & No \\
\hline & $\begin{array}{l}\text { chemical } \\
\text { hazard }\end{array}$ & Yes & Use disinfectant and wax & \begin{tabular}{|l}
$\begin{array}{l}\text { make sure all of them } \\
\text { line with national } \\
\text { standards }\end{array}$ \\
\end{tabular} & Yes \\
\hline & physical hazard & No & & & No \\
\hline \multirow{3}{*}{ Storage } & $\begin{array}{l}\text { biological } \\
\text { hazard }\end{array}$ & Yes & Fruit rot during the storage & $\begin{array}{l}\begin{array}{l}\text { Control the storage } \\
\text { condition }\end{array} \\
\end{array}$ & No \\
\hline & $\begin{array}{l}\text { chemical } \\
\text { hazard }\end{array}$ & Yes & $\begin{array}{l}\text { Use chemical anti-stalling } \\
\text { agents }\end{array}$ & limited & No \\
\hline & physical hazard & No & & & No \\
\hline \multirow{3}{*}{$\begin{array}{l}\text { Transportati } \\
\text { on }\end{array}$} & $\begin{array}{l}\text { biological } \\
\text { hazard }\end{array}$ & Yes & $\begin{array}{l}\text { Generate pathogens during } \\
\text { transportation }\end{array}$ & $\begin{array}{l}\text { control transportation } \\
\text { condition }\end{array}$ & No \\
\hline & $\begin{array}{l}\text { chemical } \\
\text { hazard }\end{array}$ & No & & & No \\
\hline & \begin{tabular}{|l|} 
physical hazard \\
\end{tabular} & No & & & No \\
\hline \multirow{3}{*}{ Sale } & $\begin{array}{l}\text { biological } \\
\text { hazard }\end{array}$ & Yes & $\begin{array}{l}\text { Generate pathogens during } \\
\text { sale }\end{array}$ & temperature control & No \\
\hline & $\begin{array}{l}\text { chemical } \\
\text { hazard }\end{array}$ & No & & & No \\
\hline & physical hazard & No & & & No \\
\hline
\end{tabular}

\section{Determination of Navel Orange Traceability Information}

In order to track and trace the safety information of navel orange, the traceability information of the whole process from orchard to market should be identified and recorded [7,8]. Generally, there are four main steps information should be acquisitioned and recorded: origin information of the orchard, planting process information, production process information and storage and transportation information.

When an orchard was selected, we should investigate land use history, soil type, soil erosion and ground water quality. Evaluate whether the regional air, soil, irrigation water and other conditions, such as soil heavy metal, suit for navel orange growing. Others information like the place of orchard, the owner of the orchard, the varieties of navel oranges should be known. 
In the planting process stage, different measures should be taken to deal with different diseases, pests. So the diseases, pests information and the information about the amount, time of chemical fertilizer, pesticide must be recorded.

During the production process, the information about the enterprise which packing the fruit, the disinfectant and wax during the washing, waxing must be tracked. In the final step before sale, we shall figure out where the navel orange storage, how the condition about the warehouse. The information about the transportation also should be recorded.

The traceability code is the unique identification of navel orange in sales link. All of the quality and safety information of the product can be obtained through this code, combined with the navel orange traceability system.

Table 3. Traceability information of navel orange

\begin{tabular}{|c|c|}
\hline $\begin{array}{l}\text { Production } \\
\text { process }\end{array}$ & Traceability Information \\
\hline \multirow{3}{*}{ Origin } & regional air quality(SO2, fluoride) \\
\hline & irrigation water quality(heavy metal pollution) \\
\hline & navel oranges varieties, place, owner \\
\hline \multirow{4}{*}{$\begin{array}{l}\text { Planting } \\
\text { process }\end{array}$} & diseases, pests information \\
\hline & amount, time of chemical fertilizer use \\
\hline & amount, time of pesticide use \\
\hline & extreme climate, employee information \\
\hline \multirow{3}{*}{$\begin{array}{l}\text { Production } \\
\text { process }\end{array}$} & disinfectant quality safety information \\
\hline & wax quality safety information \\
\hline & Enterprise, employee information \\
\hline \multirow{3}{*}{$\begin{array}{l}\text { Storage and } \\
\text { transportation }\end{array}$} & $\begin{array}{l}\text { storage surroundings information(temperature, moisture, sanitary } \\
\text { conditions) }\end{array}$ \\
\hline & $\begin{array}{l}\text { transportation information(temperature, moisture, sanitary } \\
\text { conditions) }\end{array}$ \\
\hline & enterprise and employee of transportation \\
\hline \multirow{2}{*}{ Sale } & supermarket or terminal market \\
\hline & traceability code of navel orange \\
\hline
\end{tabular}

There are many links that make navel orange infected bacteria from orchard to sale, but these hazards can generally be controlled by SSOP (Sanitation Standard Operating Procedure).

\section{Conclusion}

This paper discusses what the traceability system should trace; and which information should be recorded for implementation of the traceability system of navel orange. Three main hazards of navel orange are pointed out in the paper; those may harm consumers' health. Based on analyses the whole process from orchard selection to 
navel orange sale, as well as safety factor of navel orange, five critical control points of navel orange are determined with HACCP method. These critical control points are the focus of the traceability system; and they should be recorded precisely during the entire process. In the end of this article, the traceability information is determinate basic on the critical control points. This study makes the navel orange traceability system construction possible.

Acknowledgments. This study is supported by The National Science and Technology Support Programme (2009BADC4B04).

\section{References}

1. Liu, Y., Chen, L.: Traceability Production System of Beef in EU and USA, food science (8), 182-185 (2003)

2. $\mathrm{Pu}, \mathrm{Y}$.: Construction of traceability system for quality safety of apple and apple juice. Transactions of the Chinese Society of Agricultural Engineering 24(2), 289-292 (2008)

3. Fan, H., Feng, Z., Yang, L., Ren, A.: Appliance and Discussion of Traceability System in Food Chain. Ecological Economy 17(4), 30-33 (2007)

4. Bao, D.: Guide to implementation of HACCP. Chemical Industry Press (2007)

5. $\mathrm{Xu}, \mathrm{J}$.: Agricultural product supply chain-Guarantee food safety. China Logistics \& Purchasing (07) (2005)

6. Yu, H., An, Y.: Theoretical discussion of implementation Traceability System in food supply chain. Agricultural Quality and Standards (03) (2005)

7. Zhang, G., Chen, G.: Food safety and Traceability System. China Logistics \& Purchasing (14) (2005)

8. Zhou, Y., Geng, X.: Application of Traceability in Food Safety. Research of Agricultural Modernization (06) (2002) 